\title{
Single Cell Protein Production from Liquefied Petroleum Gas*
}

\author{
by Shinichi Kawakami**, Hideo Shoji**, Norimasa Nonaka***, \\ Mikitake Nakayama** and Takuya Hatano**
}

\begin{abstract}
Summary: A propane and butane-utilizing bacterial strain, capable of growth at a comparatively high temperature with a specific growth rate of $0.12 \mathrm{hr}^{-1}$, has been isolated from soil samples by enrichment culture. The optimum temperature and $p H$ range for the growth of the isolate, designated $S B-1701$, were $35 \sim 40^{\circ} \mathrm{C}$ and $5.7 \sim 6.7$, respectively.

Cultivation was carried out with a mixed gas of $20 \%$-butane and $80 \%$ air, using only inorganic salts as the medium. The optimum medium composition which contained trace metallic salts was determined to obtain high productivity. Continuous culture was maintained at a steady state for more than 400 hours in a 20-liter jar fermenter during which the productivity was $1.4 \mathrm{~g}$ cell/l $\cdot \mathrm{hr}$. The yield based on propane was $0.95 \mathrm{~g}$ cell $/ \mathrm{g}$ propane and the yield based on oxygen was $0.41 \mathrm{~g}$ cell $/ \mathrm{g}$ oxygen. All experiments were carried out aseptically.
\end{abstract}

$S B-1701$ has been identified as a new strain of the genus Flavobacterium.

The crude protein content and the amino acid profile of $S B-1701$ were determined.

\section{Introduction}

Processes for producing SCP (Single Cell Protein) from $n$-paraffin and methanol have already been established. Although gaseous hydrocarbon fermentation has certain problems related to bioengineering ${ }^{1)}$, there are advantages of using gaseous hydrocarbons as raw materials, such as

(i) pure raw materials can be made available in abandance

(ii) unused substrate can be removed easily from fermentation broth or biomass

A considerable number of papers on SCP production using methane as the substrate have been reported $^{2)}$, but only a limited number of papers such as those of Sugimoto et al. ${ }^{3)}$, Akiba et al. ${ }^{4}$ ) and McLee et al. ${ }^{5}$ are available on SCP production from LPG (Liquefied Petroleum Gas).

Moreover, the cultivation temperatures used in these studies were around $30 \mathrm{C}$. We consider it advantageous to cultivate the microorganisms at higher temperatures for SCP production, because the difference in temperatures between cooling water and fermentation medium will become greater and then the heat of fermentation can be effectively removed.

This paper concerns with isolation and charac-

* Received June 1, 1977.

** Bridgestone Liquefied Gas Cio., Ltd. (1-2, Kyobashi, Chuo-ku, Tokyo 104)

*** Present address: DIC Kiko Co., Ltd. (3-7-20, Nihonbashi, Chuo-ku, Tokyo 104) teristics of propane and butane utilizing bacteria which are capable of growth at temperatures above $35^{\circ} \mathrm{C}$.

\section{Materials and Methods}

\subsection{Medium and LPG}

The composition of medium A used for isolation of organisms is shown in Table 1 . The medium consists only of inorganic salts and it does not contain organic nutrients and vitamins. The initial fermentation $\mathrm{pH}$ was 6.8 , and a solid medium containing $2 \%$ agar was used for plate and stock culture. Sterilization was carried out for 15 minutes at $120^{\circ} \mathrm{C}$. The composition of medium B used to obtain high productivity, is shown in Table 1. The purity of the $n$-butane used was over $99.9 \%$ and that of the propane over $98 \%$.

Table 1 Composition of Media

\begin{tabular}{|c|c|c|}
\hline Component & $\underset{(\mathrm{g} / l)}{\text { Medium }} \mathrm{A}$ & $\underset{(\mathrm{g} / l)}{\text { Medium }} \mathrm{B}$ \\
\hline $\begin{array}{l}\left(\mathrm{NH}_{4}\right)_{2} \mathrm{SO}_{4} \\
\mathrm{KH}_{2} \mathrm{PO}_{4} \\
\mathrm{Na}_{2} \mathrm{HPO}_{4} \\
\mathrm{MgSO}_{4} \cdot 7 \mathrm{H}_{2} \mathrm{O} \\
\mathrm{FeSO}_{4} \cdot 7 \mathrm{H}_{2} \mathrm{O} \\
\mathrm{MnSO}_{4} \cdot 4 \mathrm{H}_{2} \mathrm{O} \\
\mathrm{CaCl}_{2} \cdot 2 \mathrm{H}_{2} \mathrm{O} \\
\mathrm{CuSO}_{4} \cdot 5 \mathrm{H}_{2} \mathrm{O} \\
\mathrm{ZnSO}_{4} \cdot 7 \mathrm{H}_{2} \mathrm{O} \\
\mathrm{CoCl}_{2} \cdot 6 \mathrm{H}_{2} \mathrm{O} \\
\left(\mathrm{NH}_{4}\right)_{6} \mathrm{Mo}_{7} \mathrm{O}_{24} \cdot 4 \mathrm{H}_{2} \mathrm{O} \\
\mathrm{KI}_{3} \\
\mathrm{H}_{3} \mathrm{BO}_{3}\end{array}$ & $\begin{array}{l}2.0 \\
0.5 \\
0.5 \\
0.2 \\
1.0 \times 10^{-2} \\
2.0 \times 10^{-3} \\
1.0 \times 10^{-2} \\
= \\
- \\
- \\
= \\
-\end{array}$ & $\begin{array}{l}8.0 \\
4.0 \\
0.5 \\
1.6 \\
4.0 \times 10^{-2} \\
8.0 \times 10^{-3} \\
4.0 \times 11-2 \\
9.6 \times 10^{-4} \\
9.6 \times 10^{-3} \\
4.8 \times 10^{-5} \\
1.3 \times 10^{-3} \\
8.2 \times 10^{-4} \\
4.0 \times 10^{-3}\end{array}$ \\
\hline
\end{tabular}




\subsection{Isolation of Organisms and Screening}

Bacteria were isolated by the enrichment culture method. $100 \mathrm{~m} l$ of medium A was placed in a $500 \mathrm{~m} l$ Sakaguchi flask, inoculated with about $0.5 \mathrm{~g}$ of a sample. Then air containing $20 \% n$ butane was sealed in with a cotton filter tube, and cultivation was carried out at $37^{\circ} \mathrm{C}$ on a reciprocal shaker for $1 \sim 2$ weeks. After incubation, the broth was diluted with sterilized water in the amount $5 \sim 10$ times that of the broth, streaked onto the agar plates with a loop and incubated for $4 \sim 6$ days at $37^{\circ} \mathrm{C}$. Incubation was carried out in a desiccator in an atmosphere of air containing 20\% $n$-butane. After incubation, large dense colonies on the plates were selected and transferred to the agar slants and incubated in a $n$-butane-air atmosphere and they were finally purified.

The growth rate of the isolated bacteria was obtained by batch culture. Cultivation of the isolated bacteria was carried out in a $500 \mathrm{~m} l$ Sakaguchi flask under the same conditions as those of the enrichment culture. Cell concentrations during culture were measured by following the optical densities to obtain the growth rate.

\subsection{Cell Concentration}

After centrifugation of the culture broth, the sedimented cells were washed twice with water and dried for 24 hours at $105^{\circ} \mathrm{C}$ to obtain dry cell weight ( $\mathrm{g}$ cell $/ l)$. The optical cell density (O.D.) of the broth was obtained by measuring absorbancy at $610 \mathrm{~nm}$ using a spectrophotometer (Hitachi Model 124). 1 O.D. was equal to $0.2 \mathrm{~g}$ cell $/ l$.

\subsection{Gas Analysis}

The composition of the gas at the inlet and outlet of the fermenter was analyzed by gas chromatography using a thermal conductivity detector (Shimadzu Model GC-3BT). Propane, butane and carbon dioxide levels were determined with DBM columns ( $3 \mathrm{~mm}$ dia. $\times 3 \mathrm{~m}$ ), and oxygen and nitrogen levels were determined with molecular sieves $5 \mathrm{~A}(3 \mathrm{~mm}$ dia. $\times 1.5 \mathrm{~m})$. The column temperature was $40^{\circ} \mathrm{C}$, and $40 \mathrm{ml} / \mathrm{min}$ helium was used as the carrier gas. The gas flow rate at the outlet of the fermenter was measured with a wet-type flow meter.

\subsection{Cell Analysis}

The broth cultured in a 20-liter fermenter using propane as the substrate (O.D. 80) was centrifuged, and the harvested cells were washed twice with a $0.85 \%$ physiological saline solution and dried in vacuo for 30 hours at $40^{\circ} \mathrm{C}$. The crude protein contents of the dry cells were calculated by multiplying the nitrogen content, determined by elementary analysis by 6.25 . The amino acid distribution of the dry cells was analyzed by the Japan Scientific Feeds Association.

\subsection{Identification of Strain}

Mycologic characteristics of the isolated bacteria were examined by the following methods. Gram staining was observed by the modified Hucker method ${ }^{6}$. Barsiekow medium and the synthetic medium of Ayers et al. were used for observing the acid formation from sugars. An $\mathrm{NH}_{4} \mathrm{NO}_{3}$-inorganic synthetic medium was used for observing the utilization characteristics of sugars. The O-F test was performed in accordance with the Hugh \& Leifson method. G.C. content in DNA was obtained by measuring $\mathrm{Tm}^{7}$ ) after extracting DNA by the Marmur method ${ }^{8}$. Other tests were carried out by conventional methods ${ }^{9 / 11)}$.

\subsection{Experiments with a 2-liter Fermenter}

Batch culture using a 2-liter fermenter was carried out to determine (i) the optimum growth temperature and (ii) the optimum growth $\mathrm{pH}$. One liter of medium A was charged into a standard, agitated-type 2-liter fermenter (Kanto Rikaki) and sterilized. The temperature and $\mathrm{pH}$ were maintained constant and agitation was carried out at $600 \mathrm{rpm}$. A feed gas mixture of $20 \%$ propane and $80 \%$ air was sparged at a rate of $1 \mathrm{vvm}$. The specific growth rate by O.D. measurement during culture was used as the reference for deciding the optimum condition.

\subsection{Experiments with a 20-liter Fermenter}

The optimum cultivation medium for obtaining high productivity was decided from batch culture using a 20-liter fermenter (Kanto Rikaki). Eight liters of medium A was charged into the fermenter as the basal medium. A batch culture was carried out aseptically at $37^{\circ} \mathrm{C}, \mathrm{pH} 6.1$ and agitation speed of $600 \mathrm{rpm}$. A mixed gas of $20 \%$ propane and $80 \%$ air was sparged continuously at a rate of $0.5 \mathrm{vvm}$. Inorganic salts and trace quantities of metallic salts $\left(\mathrm{Cu}^{2+}, \mathrm{Zn}^{2+}, \mathrm{Co}^{2+}\right.$, $\left.\mathrm{Mo}^{6+}, \mathrm{I}^{-}, \mathrm{B}^{3+}\right)$ were injected separately into the broth when any growth depression was observed during cultivation. The combination of medium $A$ and injected salts was taken as medium B.

\subsection{Continuous Gulture Experiment}

Experiments on continuous culture were carried out using a 20-liter fermenter. A schematic dia- 


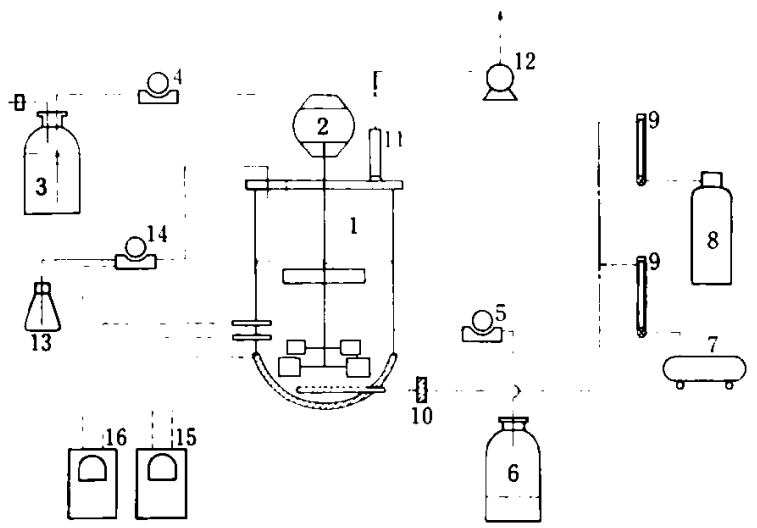

120 l Jar fermenter, 2 Moter, 3 Bottle with stock medium, 4 Metcring pump, 5 Harvesting pump, 6 Harvesting bottle, 7 Air compressor, 8 LPG cylinder, 9 Gas flow meter and controller, 10 PVA air filter, 11 Condenser, 12 Flow meter, 13 Bottle with $28 \% \mathrm{NH}_{4}$ $\mathrm{OH}$ solution, 14 Dosing pump, 15 Temperature controller, $16 \mathrm{pH}$ controller

Fig. 1 Schematic Diagram of Continuous Cultivation Apparatus

gram of the apparatus is shown in Fig. 1. Cultivation was carried out at $37^{\circ} \mathrm{C}, \mathrm{pH} 6.1$ using an agitation speed of $600 \mathrm{rpm}$. A mixed gas of $20^{\circ} \%$ propane and $80 \%$ air was sparged continuously at a rate of $0.5 \mathrm{vvm}$. The exhaust gas from the fermenter was not recycled. The liquid volume in the fermenter was maintained constant at 8 liters by means of dosing and harvesting peristaltic pumps (Tokyo Rikakikai Model MP-1011). Medium B was used in this experiment. The dilution rate was $0.06 \mathrm{hr}^{-1}$.

Productivity was calculated by the following equation.

$$
\begin{gathered}
\mathrm{P}=\mathrm{D} \cdot \mathrm{X} \\
D: \text { dilution rate, } \mathrm{hr}^{-1} \\
X: \text { cell concentration, g cell/ll}
\end{gathered}
$$

And yields based on propane and oxygen were calculated by the following equations.

$$
\begin{aligned}
Y_{\mathrm{C}} & =\frac{P}{V_{\mathrm{C}}} \\
Y_{\mathrm{O}} & =\frac{P}{V_{\mathrm{O}}}
\end{aligned}
$$

$Y_{C}:$ yield based on propane, $\mathrm{g}$ cell/g propane

$Y_{0}:$ yield based on oxygen, $\mathrm{g}$ cell $/ \mathrm{g}$ oxygen

$V_{\mathrm{C}}:$ propane uptake rate, $\mathrm{g}$ propane $/ l \cdot \mathrm{hr}$

$V_{0}$ : oxygen uptake rate, g oxygen $/ l \cdot h \mathbf{h r}$

The uptake rates of propane and oxygen were obtained from the mass balance around the fermenter, which was obtained from gas analysis and exhaust gas volume measurements.

\section{Results and Discussion}

\subsection{Isolation and Screening}

Twenty three bacterial strains capable of growth on $n$-butane as its sole carbon-energy source at $37^{\circ} \mathrm{C}$ were isolated from 31 soil samples.

The soil samples were taken from an oil seepage area in Shizuoka Prefecture. As a result of screening, SB-1701 indicated the fastest growth with a doubling time of 5 hours. The doubling time of the other bacteria was over 6 hours. It was found that SB-1701 can also utilize propane besides $n$-butane with the same growth rate.

\subsection{Identification}

The results of the identification tests are shown in Table 2. SB-1701 is a nonmotile, Gram negative and yellow rod bacteria with positive catarase and oxidase. Therefore, it was concluded that this strain belongs to the genus Flavobacterium. A comparison was made between this strain and

Table 2 Taxonomic Properties of Strain SB-1701

1. Morphological Characteristics.

Rods, 2.5-5.0 $\mu \times 0.7 \mu$, Gram-negative, Non motile, No endspores, Not acid-fast.

2. Gultural Characteristics.

1) Nutrient agar colonies. $2.5-3.0 \times 3.0-4.0 \mathrm{~mm}$, rabulate, vurrucose, pulvinate, labate, amorphous, pale reddish yellow, opaque.

2) Nutrient broth. Pellicle, Strongly turbidic, Viscid.

3) Potato slant. Abundant growth, Non soluble light reddish yellow pigments.

4) Litmus milk : Alkaline.

5) B.C.P. milk : Alkaline.

3. Biochemical characteristics.

1) Indol : Not produced.

2) Nitrate reduced to nitrite : Positive.

3) Hydrogen sulfide : Produced.

4) Urease : Positive.

5) Oxidase : Negative.

6) Catarase : Positive.

7) Starch : Not hydrolyzed.

8) Gelatin stab : Not liquefied.

9) No acid and no gas from carbohydrates.

10) D-glucose, D-mannose, D-fructose, D-galactose, sucrose, D-solbitol and D-mannitol are utilized as a sole source of carbon with ammoniacal nitrogen.

4. Physiological Characteristics.

1) Aerobic.

2. Optimum temperature : $35 \sim 40^{\circ} \mathrm{C}$.

Moles $\% \mathrm{G}+\mathrm{C}: 43.2 \%$

Table 3 Analysis of the Cell Components

\begin{tabular}{c|c}
\hline Crude Protein & $65.13 \%$ \\
\hline $\mathrm{C}$ & $44.80 \% \mathrm{~W} / \mathrm{W}$ \\
$\mathrm{H}$ & $7.33 \%$ \\
$\mathrm{~N}$ & $10.42 \%$ \\
$\mathrm{O}$ & $28.14 \%$ \\
Ash & $9.30 \%$ \\
\hline
\end{tabular}


Table 4 Amino Acid Distribution in Strain SB-1701 and Typical SCP

\begin{tabular}{|c|c|c|c|c|}
\hline \multirow[b]{2}{*}{ Amino Acid } & \multicolumn{4}{|c|}{ Source of Protein } \\
\hline & $\begin{array}{c}\text { SB-1701 } \\
\text { (Propane) }\end{array}$ & $\begin{array}{l}\left.\text { Bacteria }{ }^{12}\right) \\
\text { (Methane) }\end{array}$ & $\begin{array}{l}\left.\text { Bacteria }{ }^{19}\right) \\
\text { (Methanol) }\end{array}$ & $\begin{array}{c}\text { Yeast }^{14)} \\
n \text {-Paraf- } \\
\text { fin) }\end{array}$ \\
\hline Isoleucine & 2.89 & 3.45 & 4.30 & 5.1 \\
\hline Leucine & 6.70 & 5.61 & 6.77 & 7.4 \\
\hline Phenylalanine & 3.21 & 5.03 & 3.43 & 4.7 \\
\hline Tyrosine & 2.33 & - & 3.07 & 3.6 \\
\hline Lysine & 4.12 & 3.52 & 5.88 & 7.4 \\
\hline Gystine & 0.54 & - & 0.61 & 1.1 \\
\hline Methionine & 0.89 & 1.32 & 2.41 & 1.8 \\
\hline Threonine & 5.08 & 3.83 & 4.59 & 4.9 \\
\hline Tryptophane & 1.38 & 9.29 & 0.89 & 1.4 \\
\hline Valine & 5.09 & 12.47 & 5.23 & 5.9 \\
\hline Glycine & 4.55 & 5.14 & 5.04 & -1 \\
\hline Alanine & 8.23 & 2.19 & 6.82 & - \\
\hline Histidine & 1.63 & 2.23 & 1.53 & 2.1 \\
\hline Proline & 3.58 & 2.87 & 3.01 & - \\
\hline Serine & 2.13 & 4.30 & 3.40 & — \\
\hline Arginine & 6.12 & 5.10 & 4.47 & - \\
\hline Aspartic acid & 7.97 & 8.47 & 8.53 & - \\
\hline Glutamic acid & 14.82 & 9.09 & 9.06 & - \\
\hline
\end{tabular}

Amino acid grams/16 grams nitrogen

bacteria belonging to the genus Flavobacterium as described in Bergey's Manual of Determinative Bacteriology (8th Edition). This strain is similar to $F$. ferrugineum in its G.C. content in DNA, but it differs from $F$. ferrugineum with respect to hydrolyzed gelatin and starch and formation of acid from sugars. This strain is characterized by its optimum growth temperature of $37^{\circ} \mathrm{C}$. There are 4 kinds of strain, $F$. meningosepticum, $F$. ferrugineum, $F$. lutescens and $F$. rigense, belonging to the genus Flavobacterium which are capable of growth at $37^{\circ} \mathrm{C}$. However, SB-1701 differs from those strains in its mycologic characteristics. From the above facts, SB-1701 has been identified as a new strain belonging to the genus Flavobacterium.

\subsection{Analysis of Bacteria}

The results of elementary analysis of SB-1701 are shown in Table 3. The biomass contains a high protein concentration similar to other SCP's.

The amino acid composition of this strain and that of typical SCP's are shown in Table 4. The amino acid distribution of this strain is nearly comparable with other SCP's except for sulfur-containing amino acids.

\subsection{Growth Gharacteristics}

The optimum growth temperature of SB-1701 at $\mathrm{pH} 6.1$ was $35 \sim 40^{\circ} \mathrm{C}$, and the growth rate decreases considerably at $45^{\circ} \mathrm{C}$ (Fig. 2). The optimum $\mathrm{pH}$ range at $37^{\circ} \mathrm{C}$ was $5.7 \sim 6.7$, and at $\mathrm{pH} 4.8$ no growth was observed (Fig. 3). The maximum specific growth rate of the isolate under optimum growth conditions was $0.12 \mathrm{hr}^{-1}$.

One of the major problems in SCP production

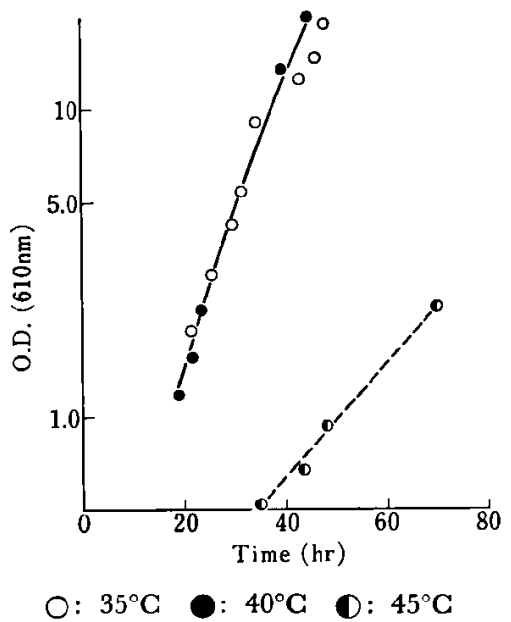

Fig. 2 Effect of Growth Temperature in Batch Culture at pH $6.12 l$ Jar Fermenter, 20\% Propane-Air Mixture, 1 vvm.

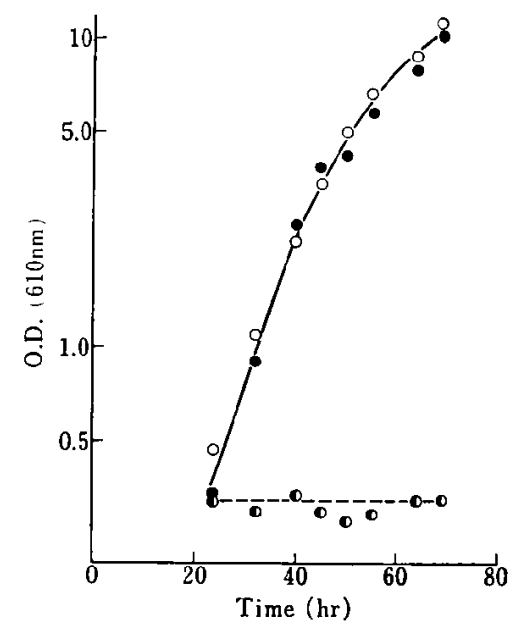

O: $\mathrm{pH} 6.7$

$$
\begin{array}{lll}
\mathrm{pH} & 5.7 & \mathrm{O} \\
\mathrm{pH} & 4.8
\end{array}
$$

Fig. 3 Effect of $\mathrm{pH}$ on Growth in Batch Culture at $37^{\circ} \mathrm{C} 2 l$ Jar Fermenter, 20\% Propane-Air Mixture, 1 vvm.

Table 5 Growth characteristics of typical propane and butane utilizing bacteria

\begin{tabular}{c|c|c|c}
\hline Organism & $\begin{array}{c}\text { Temper- } \\
\text { ature } \\
\left({ }^{\circ} \mathrm{C}\right)\end{array}$ & $\begin{array}{c}\text { Specific } \\
\text { Rate }\left(\mathrm{hr}^{-1}\right)\end{array}$ & Reference \\
\hline $\begin{array}{c}\text { Nocardia paraffinica } \\
\text { KY 4334 } \\
\text { (n-butane) }\end{array}$ & 30 & 0.077 & $3)$ \\
\hline $\begin{array}{c}\text { Corynebacterium } \\
\text { hydrocarboclastus } \\
\text { (propane) }\end{array}$ & 30 & 0.046 & $4)$ \\
\hline $\begin{array}{c}\text { Arthrobacter } \\
\text { P4 } \\
\text { (n-butane) }\end{array}$ & 30 & 0.173 & $5)$ \\
\hline $\begin{array}{c}\text { Flavobacterium } \\
\text { SB-1701 }\end{array}$ & $35 \sim 40$ & 0.116 & \\
\hline (propane and butane) & & & \\
\hline
\end{tabular}




\section{Acknowledgement}

The authors express their thanks to Mr. K. Maruyama and Mr. K. Fukuda for their assistance in this experimental work.

\section{References}

1) Takahashi, J., Petroleum and Microorganisms, (4), 24 (1970).

2) Takahara, Y., J. Ferment. Asso., 32, (7), 265 (1974).

3) Sugimoto, M., Yokoo, S., Imada, O., "Ferment. Technol. Today", Terui G. Ed., 503 (1972), Society of Fermentation Technology, Japan.

4) Akiba, T., Kajiyama, S., Fukimbara, T., J. Ferment. Technol., 51, (5), 343 (1973).

5) McLee, A. G., Kormendy, A. G., Wayman, M., Can.
J. Microbiol., 18, 1191 (1972).

6) Hucker, G. J., Abst. Bacteriol., 6, 2 (1922).

7) Marmur, J., J. Mol. Biol., 3, 208 (1961).

8) Marmur, J., Doty, P., J. Mol. Biol., 5, 109 (1962).

9) Iizuka, H., Seto, N., J. Ferment. Asso., 20, (7), 14 (1962).

10) Society of American Bacteriologists Ed., "Manual of Microbiological Methods", (1957), McGrow-Hill.

11) Smith, N. R., Gordon, R. E., Glark, F. E., "Aerobic Sporeforming Bacteria", (1952) United States Department of Agriculture.

12) Fukuoka, S., Hachiya, Y., Takahara, Y., Report of the Fermentation Research Institute (Japan), (45), 19 (1974).

13) Gow, J. S., Littbhailes, J. D., Smith, S. R. L., Walter, R. B., "Single-Cell Protein II", 370 (1975) The MIT Press.

14) Shacklady, G. A., "Single-Gell Protein II", 489 (1975), The MIT Press. 